\title{
Upland rice productivity and farming feasibility between the palm oil plant in dry land on Jambi Province
}

\author{
Jumakir $^{1, *}$, Julistia $^{\text {Bobihoe }}{ }^{1}$, Waluyo ${ }^{2}$ and Endrizal ${ }^{1}$ \\ ${ }^{1}$ Assessment Institute of Agricultural Technology (AIAT) Jambi \\ ${ }^{2}$ Assessment Institute of Agricultural Technology (AIAT) Sumatera Selatan
}

\begin{abstract}
The objectives of the study are (1) to find out the growth and productivity of upland rice, (2) to find out high upland rice varieties and the feasibility of farming between upland oil palm plants. This activity was carried out in the area of young oil palm plantations aged 2 years in Pelayangan Village, Muara Tembesi sub District, Batanghari District, Jambi Province from May to August 2016. The rice varieties were Inpago 5, Inpago 8, Inpago 9 and local upland rice with 1 ha area. The results of the study showed that the Inpago 9 variety gave the highest yield of 3.53 $\mathrm{t} / \mathrm{ha}$. The results of financial analysis show that Inpago 9 variety provides the highest income with an $\mathrm{R} / \mathrm{C}$ value of 1.54 . Inpago 9 variety has better growth and yield and resistance to drought stress than other varieties and is suitable for development in dry land. Inpago 9 variety has better growth and yield and resistance to drought stress than other varieties and is suitable for development in dry land.
\end{abstract}

\section{Introduction}

Indonesia has oil palm plantation commodities as a source of foreign exchange, a provider of employment, the main income of farmers and source of encouraging regional growth. Replanting of oil palm plants in Indonesia was a very effective effort to encourage increased production [1]. In rejuvenating/ replanting, farmers face several obstacles, namely: 1) Capital (logging of existing land, nurseries, maintenance, etc.), 2) there is a grace period between the nurseries to the garden starts to bear fruit.

Plant diversification by intercropping rice, corn and soybeans as intercrops. Utilization of oil palm land with intercropping is an effort to increase the use of agricultural land resources into agricultural land for food crops, horticulture and plantations through efforts to improve and increase the carrying capacity of the land, so that it can become more productive farming land [2]. One of the efforts to increase production is to adjust the system or the best spacing so that it is optimum to get light.

\footnotetext{
* Corresponding author: jumakirvilla@gmail.com
} 
According to [3], research results show that around 65 percent of TBM 3 can be planted with intercropping and supports the growth of oil palm. One of the cultivated food crops is upland rice which can be planted on dry land and is drought tolerant. According to [4], drought is the most important environment in affecting agriculture at large. Drought is one of the main constraints in rice production because it can decrease the amount of filled grain [5]. Another obstacle is soil acidity and poor nutrients. The main elements needed to increase production are in the presence of nitrogen, phosphate and potassium elements [6] land oil palm plants, (2) to find out the high productivity of upland rice and the feasibility of farming between dry land oil palm plants.

\section{Methodology}

This activity was carried out in Pelayangan Village, Muara Tembesi sub District, Batanghari District, Jambi Province from May to August 2016. The upland rice varieties of Inpago 5, Inpago 8, Inpago 9 and local upland rice with planting area 1 ha. Land preparation by land clearing is carried out with the aim that the land is easily cultivated and free from coconut beetle larvae. Soil processing is done to loosen the soil so that it can be planted with rice crops. The treatment includes the use of ameliorant materials such as dolomite 1000-2000 kg/ha. Rice fertilizer dosage is $150 \mathrm{~kg} / \mathrm{ha}$ Urea, $100 \mathrm{~kg} / \mathrm{ha} \mathrm{SP} 36$ and $50 \mathrm{~kg} / \mathrm{ha} \mathrm{KCl}$. Maintenance includes weeding done manually and spraying with herbicides, fertilizing is done by means of scattering, while pest control is carried out by spraying insecticides and fungicides.

The parameters observed were crop performance, plant height, productive tillers number, panicles number/clumps, filled grains number/panicles, empty grains number /panicles, harvest age, and yield. Growth and yield data are tabulated. The economic analysis used is the analysis of revenue, income and $\mathrm{R} / \mathrm{C}$ [7].

1. Analysis of farm income:

$$
\prod_{I=1} \stackrel{n}{n} \text { Y.Py }-\sum^{X} X i \cdot P x i-B L
$$

Where:

$\begin{array}{lc}\pi=\text { Net farm income } & \text { (IDR/ha) } \\ \mathrm{Y}=\text { Total production } & \text { (IDR/ha) } \\ \mathrm{Py}=\text { Selling price of rice } & \text { (IDR/kg) } \\ \mathrm{Xi}=\text { Level of farm input use } & \text { (IDR/ha) } \\ \mathrm{Pxi}=\text { Price of farming inputs } & \text { (IDR/kg) } \\ \mathrm{BL}=\text { other costs } & \text { (IDR/ha) }\end{array}$

2. Farming feasibility $(\mathrm{R} / \mathrm{C})$

$$
R / C=\frac{B T}{N P T}
$$

Where:

$\mathrm{R} / \mathrm{C}=$ Ratio of receipts and fees

$\mathrm{NPT}=$ Value of total production $\quad(\mathrm{IDR} / \mathrm{ha})$

$\mathrm{BT}=$ Value of total costs $\quad$ (IDR/ha) 
Under the condition:

$\mathrm{R} / \mathrm{C}>1$, farming is economically profitable

$\mathrm{R} / \mathrm{C}=1$, farming is economically at the break-even point (BEP)

$\mathrm{R} / \mathrm{C}<1$, farming is economically unprofitable

(loss)

\section{Results and discussion}

\subsection{Rice Plant Growth}

The percentage of growing rice plants that are tested more than 80 percents, the high percentage of growth is caused by the quality seeds, the availability of nutrients in the soil with the addition of dolomite and organic fertilizer (Table 1). The addition of organic matter, in addition to increasing soil organisms, also increases fertility and reduces acidity or increases soil $\mathrm{pH}$, as well as biological control agents against soil borne pathogens [8]. Furthermore [9], that the organic matter is important to increase soil fertility, physical, biological and chemical properties of soil.

Rice plants growth showed moderate to good performance for all varieties, and entering the generative phase it was seen that rice growth was quite diverse. From the four varieties tested, it showed that Inpago 8 and Inpago 9 varieties showed good plant growth and local rice and Inpago 5 showed moderate and quite good growth. This is thought to be the influence of the oil palm canopy. According to [10], the interception of light under the oil palm canopy is limited so that it affects various cultivated plants in the gawangan. Limited light will affect the vegetative and generative growth of rice. Furthermore [11] that differences in rice varieties will result in the amount of chlorophyll content and the ratio of chlorophyll $\mathrm{a} / \mathrm{b}$ that are not the same as different light.

Pests that appear in rice plantations are ground bugs, white pests, leaf rollers, sundep, stink bugs and birds. While the disease is like a blast. Pests/diseases control by spraying insecticides/functionicides while controlling pests of birds is guarded by farmers.

Cropping patterns interspersed with planting resistant varieties can suppress pathogen development [12]. Furthermore [13], which in areas where blast disease is endemic, especially neck blast, damage to rice plants can be reduced by taking into account the time the rice plants flower, cultivated not in conjunction with high rainfall.

Table 1. Growth of rice plants, plant height, number productive tillers and harvest age of upland rice young palm oil plants.

\begin{tabular}{|l|l|c|c|c|c|c|}
\hline No & Variety & $\begin{array}{c}\text { Growth } \\
\text { percentage } \\
(\boldsymbol{\%})\end{array}$ & $\begin{array}{c}\text { Plant } \\
\text { performance }\end{array}$ & $\begin{array}{c}\text { Plant } \\
\text { height } \\
(\mathbf{c m})\end{array}$ & $\begin{array}{c}\text { Number of } \\
\text { tillers } \\
\text { productive }\end{array}$ & $\begin{array}{c}\text { Age of } \\
\text { harvest } \\
\text { (days) }\end{array}$ \\
\hline 1. & Inpago 5 & $80-90$ & $3-5$ & 121.00 & 10.80 & 118.00 \\
\hline 2. & Inpago 8 & $80-90$ & 3 & 117.20 & 14.60 & 119.00 \\
\hline 3. & Inpago 9 & $80-90$ & 3 & 110.00 & 16.60 & 109.00 \\
\hline 4. & Local rice & $80-90$ & $3-5$ & 158.00 & 9.80 & 150.00 \\
\hline
\end{tabular}

From Table 1 above it can be seen that the highest rice plant height is $158.00 \mathrm{~cm}$ (local rice) higher than other varieties, while the lowest plant height in Inpago 9 variety is 109.00 $\mathrm{cm}$. This is caused by genotyping factors of each variety as well as environmental factors that affect plant growth. Environmental factors are clearly related to plant growth. In addition, plant growth is influenced by genetic factors [14]. Plant height is one of the criteria for rice growth, but high growth does not guarantee productivity. Plant height has a 
large influence on the relationship between panicle length and yield. The number of productive tillers of each variety is quite diverse, Inpago 9 variety has more number of tillers than other varieties. According to [15], the difference in plant height and number of productive tillers is influenced by plant varieties.

The highest number of productive tillers was Inpago 9 followed by Inpago 8, while the lowest number of tillers was 9.8 (local rice). The diversity of the number of productive tillers due to genotypic differences of each variety. According to [16], differences in plant height and number of productive tillers are affected by varieties. The number of productive tillers is the main supporting factor for the potential yield is one of the parameters that directly influences the yield. This is in line with the results of research by [15], which showed that the growth of rice plants, especially the number of tillers, was influenced by differences in genotypes.

\subsection{Results and Results Components}

In Table 2 it can be seen that the age of harvest of all superior varieties depends on the varieties planted, ranging from 109 days after planting (DAP) to 119 DAP, differing from the harvest age of local varieties reaching $150 \mathrm{DAP}$. This is consistent with the results of research that harvest age is divided into three categories, namely very early age (90-104 DAS), early age (105-124 DAS), moderate (125-164 DAS), and deep (> 165 DAS). In the tropics, the optimum age for varieties to have high yields is 120 days.

Table 2. Panicle length, number of filled grains and number of empty and yield upland rice plants between young oil palm plants.

\begin{tabular}{|l|l|c|c|c|c|}
\hline No & Variety & $\begin{array}{c}\text { Panicle } \\
\text { length }(\mathbf{c m})\end{array}$ & $\begin{array}{c}\text { Number of filled } \\
\text { grains / panicles }\end{array}$ & $\begin{array}{c}\text { Number of empty } \\
\text { grains / panicles }\end{array}$ & $\begin{array}{l}\text { Results } \\
\text { (t/ha) }\end{array}$ \\
\hline 1. & Inpago 5 & 23.80 & 67.20 & 25.40 & 2.83 \\
\hline 2. & Inpago 8 & 27.40 & 83.40 & 49.60 & 3.37 \\
\hline 3. & Inpago 9 & 27.60 & 110.40 & 46.00 & 3.53 \\
\hline 4. & Local rice & 29.30 & 65.00 & 76.00 & 2.06 \\
\hline
\end{tabular}

The results of the study showed that the longest panicle length was $29.30 \mathrm{~cm}$ local rice while the shortest panicle length was $23.80 \mathrm{~cm}$ in the Inpago 5 variety. The number of filled grains showed the Inpago 9 variety more than the other varieties. The highest amount of filled grain was 110.40 (Inpago 9), while the highest filled grain was 65.00 obtained by local rice. The lowest number of empty grains was 25.40 in Inpago 5 variety and the highest number of empty grains was 76.00 in local rice. Empty grain will have an effect on rice yield, the higher the percentage of empty grain, the greater the effect on yield. According to [17], stated that the decrease in grain weight can be influenced by high air temperatures which triggers reduced source and sink activity as well as accelerated senescence in panicles, and has an effect on decreasing pollen fertility at the time of flowering, because the flowering stage is the stage. The most sensitive to high temperature stress.

The results of several rice varieties per hectare show that different varieties affect the yield of rice (Table 2). From Table 2 it can be seen that the highest rice yield was found in Inpago 9 variety, which was $3.53 \mathrm{t} / \mathrm{ha}$, while the lowest was obtained by local rice, 2.06 $\mathrm{t} / \mathrm{ha}$. The difference in varieties of a plant is caused by differences in genotype, plant habitus and environmental factors. The results of various varieties are different because the character of each variety is different. Environmental factors that affect the field are low 
rainfall resulting in low rice growth and yield. Rice growth and yields are influenced by weather factors, especially the reproductive and ripening phases, namely the number of panicles and unhulled rice are the yield components most sensitive to temperature stress, solar radiation, and water deficit [18]. Furthermore [19], reported that limited light will decrease various biochemical components of rice plants, thereby reducing starch, amylose, sucrose, carbohydrates and total dry weight. Meanwhile [20], inform that in moderate shade conditions will reduce the amount of light reaching the leaf surface, where the light drop to a certain level, namely 50 percent.

\subsection{Analysis of Rice Farming}

The results of analysis show that farm receipts and revenues are quite diverse (Table 3). The acceptance Inpago 9 of IDR 12,355,000, Inpago 8 of IDR 11,795,000 while Inpago 5 and Local rice varieties are IDR 9,905,000 and IDR 7,210,000, respectively. The income of IDR 4,328,000 (Inpago 9) and the lowest income obtained by local rice is IDR 1,383,000 while the income of Inpago 5 and Inpago 8 varieties are IDR 2,178,000 and IDR 3,838,000. When viewed from farm efficiency, the $\mathrm{R} / \mathrm{C}$ ratio of rice farming for each variety are 1.28 (Inpago 5), 1.48 (Inpago 8), 1.54 (Inpago 9) and 1.23 (Local rice).

Table 3. Analysis farming of upland rice between young oil palm plants

\begin{tabular}{|c|c|c|c|c|}
\hline DESCRIPTION & Inpago 5 & Inpago 8 & Inpago 9 & Local rice \\
\hline \multicolumn{5}{|l|}{ INPUT (IDR) } \\
\hline \multicolumn{5}{|l|}{ Production Facilities } \\
\hline - Seed & 400,000 & 400,000 & 400,000 & 400,000 \\
\hline - Dolomite & $1,000,000$ & $1,000,000$ & $1,000,000$ & - \\
\hline - Urea & 360,000 & 360,000 & 360,000 & 120,000 \\
\hline - SP 36 & 260,000 & 260,000 & 260,000 & 130,000 \\
\hline$-\mathrm{KCl}$ & 400,000 & 400,000 & 400,000 & 200,000 \\
\hline - Round up & 400,000 & 400,000 & 400,000 & 400,000 \\
\hline - DMA & 112,000 & 112,000 & 112,000 & 112,000 \\
\hline - Amistartop & 240,000 & 240,000 & 240,000 & 240,000 \\
\hline - Virtako & 315,000 & 315,000 & 315,000 & 315,000 \\
\hline Amount & $3.487,000$ & $3,487,000$ & $3,487,000$ & $1,917,000$ \\
\hline \multicolumn{5}{|l|}{ Labor } \\
\hline - Grass spray & 280,000 & 280,000 & 280,000 & 280,000 \\
\hline - Planting & $2,000,000$ & $2,000,000$ & $2,000,000$ & $2,000,000$ \\
\hline - Fertilizing & 150,000 & 150,000 & 150,000 & 150,000 \\
\hline - Weeding & 300,000 & 300,000 & 300,000 & 300,000 \\
\hline $\begin{array}{l}\text { - Control of pests and } \\
\text { diseases }\end{array}$ & 300,000 & 300,000 & 300,000 & 300,000 \\
\hline - Harvesting / Processing & $1,210,000$ & $1,440,000$ & $1,510,000$ & 880,000 \\
\hline Amount & $4,240,000$ & $4,470,000$ & $4,540,000$ & $3,910,000$ \\
\hline Total & $7,727,000$ & $7,957,000$ & $8,027,000$ & $5,827,000$ \\
\hline \multicolumn{5}{|l|}{ OUTPUT } \\
\hline - Yield (kg) & 2,830 & 3,370 & 3,530 & 2,060 \\
\hline - Price (IDR) & 3,500 & 3,500 & 3,500 & 3,500 \\
\hline - Receipt (IDR) & $9,905,000$ & $11,795,000$ & $12,355,000$ & $7,210,000$ \\
\hline - Income (IDR) & $2,178,000$ & $3,838,000$ & $4,328,000$ & $1,383,000$ \\
\hline$-\mathrm{R} / \mathrm{C}$ & 1.28 & 1.48 & 1.54 & 1.23 \\
\hline
\end{tabular}


This shows that the four types of rice farming provide benefits. However, the $\mathrm{R} / \mathrm{C}$ ratio in the Inpago 9 and Inpago 8 is better than the $\mathrm{R} / \mathrm{C}$ ratio in the Inpago 5 and local rice. Thus, financially, Inpago 9 rice crop is the most superior new variety. The application of introduced technology some superior varieties of upland rice have a significant effect compared to the existing technology in the form of the use of local varieties, this is indicated by the level of profits obtained by superior varieties higher than local.

\section{Conclusion}

The performance of Inpago 8 and Inpago 9 varieties has better growth compared to Inpago 5 and local rice varieties. The highest yield Inpago 9 of $3.53 \mathrm{t} / \mathrm{ha}$. The results of the financial analysis of superior varieties of Inpago 5, Inpago 8 and Inpago 9 give higher profits than local varieties. Inpago 9 variety gives the highest income of IDR 4,328,000.

Acknowledgements. The authors wish to acknowledge and thanks say thank you for the support to the head of Assessment Institute Agricultural Technology Jambi.

\section{References}

1. H. Wibowo, dan A. Junaedi. Bul. Agrohorti 5 (1): 107 -116 (2017)

2. Ditjen PSP. Pedoman Umum Optimalisasi Lahan (2015)

3. M. Sarwendah. Tesis Program Pascasarjana Fakultas Pertanian. Universitas Gajah Mada Yogyakarta (2015)

4. S. Yang, B. Vanderbeld, J. Wan, and Y. Huang. Narrowing Down the Targets: Towards Successful Genetic Engineering of Drought-Tolerant Crops (2010)

5. Z. Rang, S. Jagadish, Q, Zhou, P. Craufurd, S. Heuer. Environmental and Experimental Botany. 70 (2011) 58-65 (2011)

6. S. Samuel, S. Muthukkaruppan. Current Botany. 2(3): 22-25 (2011)

7. R. Hendayana. Alat Analisis Data Untuk Karya Tulis Ilmiah (2015)

8. E. Klein, J. Katan, and A. Gamliel. Plant Dis. 95: 1116-1123 (2011)

9. Q. Zhang, Zhou, W. Liang, G. Wang, X. Sun, J. He, and L. Li. PLoS One, 10(4): 119 (2015)

10. L. Qi Hua, W Xiu, C. Bo cong, MA. Jia Qing, G. Jie. Rice Science, 2014, 21(5): 243-251 (2014)

11. C. Chen, MY. Huang, KH. Lin, SL. Wong, WD. Huang, CM. Yang. J. Biotech. 9(4):15 (2014)

12. S. Pradhan, D. Nayak, E. Pandit, L. Behera, A. Anandan, A. Mukherjee, S. Lenka, and D. Barik. Phytopathology 106: 710-718 (2016)

13. R. Gallet, C. Fontaine, F. Bonnot, J. Milazzo, C. Tertois, H. Adreit,V. Ravigne, E. Fournier, and D. Tharreau. Phytopathology 106: 348-354 (2016)

14. K. Johnson and M. Lenhard. Genetic Control of Plant Organ Growth. New Phytologist (2011). 
15. K. Sasaki, S. Ikeda, S. Eda, H. Mitsui, E. Hanzawa, C. Kisara, Y. Kazama, A. Kushida, T. Shinano, K. Minamisawa, dan T. Sato. Soil Sci. and Plant Nut. 56: 636-644 (2010)

16. E. Mulyaningsih, H Sukiman, T Ermayanti, S Lekatompessy, S Indrayani, A Seri, dan E Mei Adi. JPPTP. 18(3): 251-261 (2015)

17. J. Kim, Y. Choi, S. Lee, Y. Koh. Genotype Variation for Toleran to Phosphorus Deficiency in Rice and the Potential for its Exploitation in Rice Improvement (2011)

18. V. Sridevi and V. Chellamuthu. IJAR 1(9): 825- 831 (2015)

19. S. Dutta, W. Tyagi, and M. Rai. Agricultural Reviews, 38(3): 209-215(2017)

20. R.Hermann and G. Garces. Agronomía Colombiana 31(2):195-200(2013) 